\title{
Black thread scale, Ischnaspis longirostris (Signoret) (Insecta: Hemiptera: Diaspididae) 1
}

Adriana Espinosa, Amanda Hodges, Greg Hodges and Catharine Mannion²

\section{Introduction}

The black thread scale, Ischnaspis longirostris (Signoret), is native to Africa, and was first reported from Florida in 1908. It is a very polyphagous species whose host range includes over 50 plant families and 130 genera. Black thread scale is considered one of the 43 most serious worldwide armored scale (Hemiptera: Diaspididae) pests (Miller and Davidson 2005).

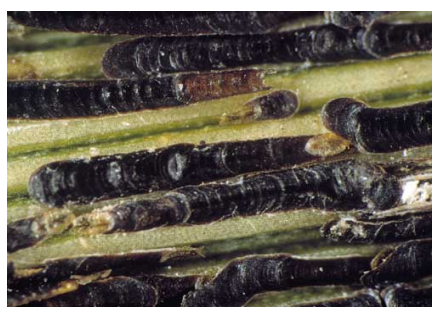

Figure 1. Infestation of black thread scale, Ischnaspis longirostris (Signoret). Credits: Photograph by: FDACS-Division of Plant Industry

\section{Distribution}

This species is most commonly found in tropical and subtropical areas throughout the world. It is reported as present in North, Central, and South America; Asia, Australia, the Caribbean, and Africa. (Dekle 1965, Miller and Davidson 2005, Miller et. al. 2009).

\section{Field Characteristics}

Adult females have a yellow body, with an elongated shiny black cover. The scale cover is typically eight to 10 times longer than wide, usually measuring 0.078 to 0.138 inches ( 2 to $3.5 \mathrm{~mm}$ ) in length. The cast skin is pale yellow to light brown, and usually visible at the marginal edges of the scale cover. Eggs are orange and crawlers are yellow. It takes crawlers about three days to molt to the elongated second instar. Black thread scale reproduces by parthenogenis (without mating), and no males have been observed (Dekle 1965, Howard et al. 2001, Miller and Davidson 2005).

1. This document is EENY-450, one of a series of Featured Creatures from the Entomology and Nematology Department, Florida Cooperative Extension Service, Institute of Food and Agricultural Sciences, University of Florida. Published: June 2009. This document is also available on Featured Creatures website at http://entomology.ifas.ufl.edu/creatures. Please visit the EDIS website at http://edis.ifas.ufl.edu. Additional information on these organisms, including many color photographs, is available at the Entomology and Nematology Department website at http://entnemdept.ifas.ufl.edu/

2. Adriana Espinosa, Amanda Hodges, SPDN assistant director in entomology and training/education, Department of Entomology and Nematology, Gainesville, FL, Greg Hodges, Florida Department of Agriculture and Consumer Services, Division of Plant Industry, Gainesville, Fl, Catharine Mannion, Associate Professor,Tropical REC-Homestead, FL.

The Institute of Food and Agricultural Sciences (IFAS) is an Equal Opportunity Institution authorized to provide research, educational information and other services only to individuals and institutions that function with non-discrimination with respect to race, creed, color, religion, age, disability, sex, sexual orientation, marital status, national origin, political opinions or affiliations. U.S. Department of Agriculture, Cooperative Extension Service, University of Florida, IFAS, Florida A. \& M. University Cooperative Extension Program, and Boards of County Commissioners Cooperating. Millie Ferrer-Chancy, Dean 


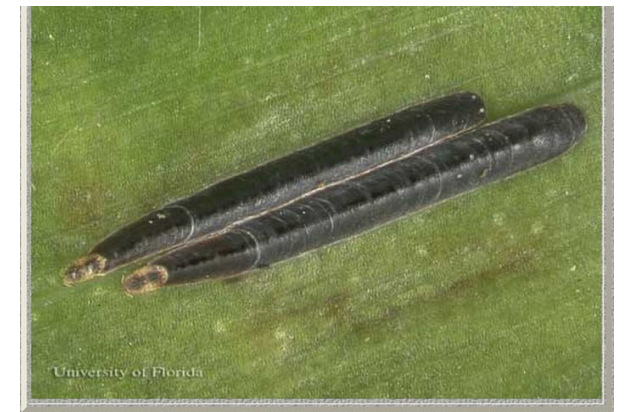

Figure 2. Adult female black thread scales, Ischnaspis longirostris (Signoret). Credits: Photograph by: Lyle J. Buss, University of Florida

\section{Life Cycle}

Each female produces 20-30 eggs. Eggs hatch soon after they are laid and crawlers find their feeding sites within 24 hours. The entire life cycle is completed in approximately 30 days (Miller and Davidson 2005, Tenbrink and Hara 1992).

\section{Hosts}

Over 50 families of host plants are attacked, including the following:

Agavaceae - Agave americana (century plant)

Anacardiaceae - Mangifera spp. (mango)

Apocynaceae - Nerium oleander (oleander), Plumeria acutifolia (frangipani tree, temple tree)

Araceae - Anthurium scandens, Dieffenbachia seguine, Philodendron spp.

Arecaceae - numerous palm species: commonly found on Chamaedorea elegans (parlor palm), Elaeis spp. (oil palms) and Monstera deliciosa (ceriman, swiss cheese plant, fruit salad plant, Mexican breadfruit) and Elaeis spp. (oil palms)

- Bromeliaceae - Bromelia sp.

- Cyperaceae - Cyperus sp.

- Fabaceae - Acacia spp.

- Lauraceae - Cinnamomum spp., Persea americana (avocado)

- Liliaceae - Aloe spp.
- Magnoliaceae - Magnolia sp.

- Malvaceae - Gossypium sp. (cotton), Hibiscus sp.

- Moraceae - Ficus spp.

- Myrtaceae - Eucalyptus sp., Eugenia sp.

- Oleaceae - Jasminum spp., Ligustrum japonicum (Japanese privet)

- Orchidaceae - Cattleya sp., Oncidium sp.

- Rosaceae - Prunus armeniaca (apricot), Rubus sp.

- Rubiaceae - Coffea spp. (coffee), Ixora sp., Gardenia sp.

- Rutaceae - Citrus spp., Litchi spp.

- Theaceae - Camellia spp.

- Verbenaceae - Duranta sp., Lantana sp.

A complete host reference list is available at ScaleNet: A Database of Scale Insects of the World.

\section{Plant Damage and Economic Importance}

This insect feeds on plant fronds, petioles and fruit. Feeding on fronds tends to occur parallel to leaf veins on the lower surface for light infestations (Miller and Davidson 2005).

Some reported hosts of economic concern include palms, greenhouse floriculture crops, coffee, cinnamon, mango, litchi, coconut, mango, avocado, and banana. Chlorosis resulting from heavy infestations can result in yield loss as well as aesthetic damage (Miller and Gimpel 2009).

\section{Management}

Management of scale insects begins with detection and identification of the pest. Scale insects can be very small or resemble disease organisms or even plant structures, making detection difficult. Regular monitoring will allow for detection of these pests before damage is obvious and will also allow improve control. All plant parts need to be searched, 
including the undersides of leaves and stems.

Inspection of plants prior to introducing them into the landscape, nursery or collection is very important in reducing new infestations of scales.

Management can be difficult because of the waxy covering which provides protection from many insecticides. Pruning or washing infested plant parts can be helpful in reducing scale populations, particularly in cases of small infestations. A brisk wash spray of water can also be helpful in removing scales from plants and reducing the population.

Scale insects are commonly attacked by predators, parasites and diseases which can help manage scale populations, particularly for long term control. It is important to recognize the presence of beneficial insects and to take steps to conserve them in the environment so they are available to control the pest insects. Ladybird beetles, specifically Chilocorus nigritus (Fabricius) and Chilocorus distigma (Klug), are somewhat effective in controlling the black thread scale. Other reported natural enemies include the hymenopteran parasitoids Aphytis chrysomphali (Mercet) and Coccophagus caridei (Brethes) (Herting and Simmonds 1972).

It is often necessary to manage scale insects with insecticides so it is important to select appropriate insecticides, timing and application methods to reduce negative impact on the natural enemies while obtaining maximum control.

Contact insecticides commonly provide quick knockdown of the pest but require good coverage and generally repeat applications. The stage most susceptible to contact insecticides is the crawler stage.

Horticultural oil and insecticidal soaps also can provide good control, but must be treated like contact insecticides, which require thorough coverage and repeat applications.

Systemic insecticides can provide excellent options for scale control and can provide some flexibility in application timing and methods. These insecticides move through the plant and provide an excellent way to expose scale insects to the insecticide when they feed on the plant.
It is important not to overuse or misuse insecticides which can lead to numerous problems, including insecticide resistance. To avoid insecticide resistance, it is critical to rotate among insecticide groups.

Florida Insect Management Guide for Scale Insects and Mealybugs on Ornamental Plants http://edis.ifas.ufl.edu/MG005

Florida Insect Management Guide for Commercial Foliage and Woody Ornamental Arthropod \{Pest Management

http://edis.ifas.ufl.edu/ig012

Florida Citrus Pest Management Guide: soft-bodied insects attacking foliage and fruit

http://edis.ifas.ufl.edu/document_cg004

\section{Selected References}

Buss EA,Turner JC. (June 2006). Scale Insects and Mealybugs on Ornamental Plants. EDIS. http://edis.ifas.ufl.edu/MG005 (7 May 2009).

Dekle GW. 1965. Arthropods of Florida and Neighboring Land Ares: Florida Armored Scale Insects. Vol. 3. Florida Department of Agriculture, Division of Plant Industry. Gainesville, FL.

Herting B, Simmonds FJ. 1972. A Catalogue of Parasites and Predators of Terrestrial Arthropods. Farnham Roy, U.K. 210 pp.

Howard FW, Moore D, Giblin-Davis RM, Abad RG. 2001. Insects on Palms. CABI Publishing. Oxon, UK. 400 pp.

Miller DR, Davidson JA. 2005. Armored Scale Insect Pests of Trees and Shrubs (Hemiptera: 
Diaspididae). Cornell University Press. Ithaca, NY. $456 \mathrm{pp}$.

Miller DR, Gimpel ME. (2009). Diaspididae:

Diaspidinae and Leucaspidinae. ScaleNet.

http://www.sel.barc.usda.gov/scalenet/scalenet.htm (7 May 2009).

Miller DR, Rung A, Venable GL, Gill RJ. (August 2007). Scale Insects: Identification tools, images, and diagnostic information for species of quarantine significance. Systematic Entomology Laboratory USDA-ARS.

http://www.sel.barc.usda.gov/scalekeys/

ScaleInsectsHome/ScaleInsectsHome.html (7 May 2009).

Tenbrink AL, Hara AH. (2002). Ischnaspis longirostris (Signoret), black thread scale. Crop Knowledge Master. http://www.extento.hawaii.edu/Kbase/Crop/Type/ i_longin.htm (11 May 2009). 